\title{
EXPLORING THE TERTIARY EFL STUDENTS' ACADEMIC WRITING COMPETENGIES
}

\author{
Aunurrahman' \\ Fuad Abdul Hamied ${ }^{2}$ \\ Emi Emilia ${ }^{3}$ \\ IKIP-PGRI Pontianak' \\ Universitas Pendidikan Indonesia ${ }^{2,3}$ \\ yarrha@gmail.com
}

First received: 22 February 2017

Final proof received: 26 May 2017

\begin{abstract}
For tertiary English as a Foreign Language (EFL) students, academic writing is not an easy task. It requires knowledge of the academic writing genres with their particular linguistic features. Moreover, academic writing demands good critical thinking. This research aims to explore the students' academic writing competencies that also focus on critical thinking. The research involved thirty-six first-year tertiary EFL students from a regular class of a private university in Pontianak, West Kalimantan, Indonesia. The source for data collection was the students' texts. Three texts were selected and the students were categorized into low, medium, and high levels of writing achievement. The text analysis utilized functional grammar rooted in systemic functional linguistics (Emilia, 2014). The analysis shows that the students, regardless of their levels of writing achievement, have little control over the schematic structure and linguistic features of an argumentative writing. The text analysis also shows that the students' texts have some limitations as regards their critical thinking capacity. Still, a few examples of academic language were detected in the texts. The findings suggest that the lecturer should incorporate explicit teaching and cooperative learning activities to alleviate the students' difficulties and develop their academic writing and critical thinking capacity.
\end{abstract}

Keywords: EFL; academic writing; writing competencies; argumentative writing

In Indonesia, writing competencies are syllabuswise covered from primary to tertiary level of education. Ideally, with this very long process, the students' writing should meet the common requirements, including acceptable grammar, conventions, and lexical choices. Unfortunately, this does not always unfold. The tertiary students' academic writing competencies in Indonesia were regarded as weak (Nugraha, 2015). Even White (1988) found that argument essays were challenging for Indonesian graduate students to write. Therefore, the aim of this research is to explore the tertiary English as a foreign language (EFL) students' academic writing competencies. In this study, the competencies also include the students' critical thinking (CT) capacity.

In this study, the competencies of academic writing require the knowledge base of a particular discipline (Maguire, Reynolds, \& Delahunt, 2013) or background knowledge of what to write (Irvin, 2010), followed by the knowledge of a particular text that has a social function and patterns of organization with a system of language (Bruce, 2008, 2013). These features are known as discourse competencies that serve as the competencies that enable an individual to communicate his or her idea into a unified text using certain language structures (Celce-Murcia, Dörnyei, \& Thurrell, 1995; Dörnyei $\&$ Thurrell, 1991). This nature of the discourse competencies coincides with systemic functional linguistics (SFL) that covers the text type or genre with its linguistic features (Derewianka, 2015; Martin \& Rose, 2008). The genre of academic writing is known as argumentative writing, which is an important genre at the university level (Coffin \& Donohue, 2012) because it can reflect a writer's critical thinking capacity (DasBender, 2011).

Argumentative writing has two distinct functions: 'persuading that' or analytical function and 'persuading to' or hortatory function (Martin, 1992). Both functions are represented by exposition and discussion genres. The two genres have a similar purpose, which is to argue with analytical and hortatory functions. The difference is the schematic structure of the genres. An exposition is written to argue an issue or a thesis from the point of view followed by arguments that support the thesis, summary, and recommendation if necessary.

Meanwhile, a discussion is written to argue an issue from at least two points of view, followed by arguments consisting of 'arguments for' and 'arguments against' the issue, and followed by a judgment or a position toward the issue and recommendation if required (Coffin, 2004; Emilia, 2012). The schematic structure of an argumentative writing can also indicate information-organizing skills of a critical thinker where a writer learns to construct a writing by providing relevant arguments 
with their supporting details in a logical manner (Ennis, 1993; Lipman, 2003).

Then, academic writing should employ certain linguistic features that are known as academic language (Schleppegrell, 2012). In particular, academic writing should use complex, formal, objective, hedged, precise, clear or explicit, and accurate language (Gillett, 2017). The first four language characteristics of academic writing, that is, complexity, formality, hedging, and objectivity are mainly related to the linguistic features of argumentative writing. The explanation of the four characteristics are as follows:

1. Complexity in academic writing is characterised by longer words with more grammatical complexity, noun-based phrases, subordinate clauses, and passive forms (Gillett, 2017).

2. The noun-based phrases that are known as nominalisation or grammatical metaphor under functional grammar and impersonal passive forms also realise objectivity in academic writing (Knapp \& Watkins, 2005).

3. The formal language is characterised by using a suitable language in an academic context that should avoid abbreviated forms such as "doesn't" (Gillett, 2017).

4. The hedged language or hedging is a cautious language that is used to show the writer's stance and the strength of the writer's claims of a particular issue in his or her academic writing (Emilia, 2009; Gillett, 2017; Gillett, Hammond, \& MartalaLockett, 2009). This characteristic is realised through certain linguistic features such as modalities, mental processes, and circumstances (Gillett, 2017).

Up to this point, these four language characteristics of academic writing are in accordance with the linguistic features of argumentative writing that are suitable to be used in an academic context. Then, the other three characteristics of the academic language, that is, clarity, precision, and accuracy are realised in academic writing through the use of intellectual standards or dispositions of $\mathrm{CT}$, that is, precision providing specific details of information or evidence and accuracy - using accurate lexical choices and grammatical forms in addressing a certain issue (Elder \& Paul, 2013; Gillett, 2017). Then, clarity or explicitness is more than just providing relevant evidence with its source or reference and or example to support one' argument as a CT disposition (Elder \& Paul, 2010) but also how every part of a text is related explicitly and logically such as through cohesive devices (Gillett, 2017) and circumstances (Emilia \& Hamied, 2015), which are also important linguistic features of an argumentative writing (Derewianka, 1990).

To be clear, CT is more than just a set of skills. It also has dispositions or intellectual standards, which are character values that act as a set of rules or guidance in a critical thinking practice (Ennis, 1996, 2013, 2016; Siegel, 2010).

Still in relation to $\mathrm{CT}$, there are also fallacies in reasoning that should be paid attention when a writer constructs an argument. To mention a few, the fallacies in reasoning are as follows:

1. Provincialism - the tendency to accept or reject ideas on the basis of experience in one's own group or society;

2. Ad hominem - an attack on a person's credibility or character rather than on the arguments presented;

3. False dilemma;

4. Hasty conclusion or generalization;

5. Begging the question, circularity. (cited in Kurfiss, 1997, pp. 15-16).

Besides the academic writing genre and its linguistic features that can reflect the students' CT capacity, an important feature in academic writing is responsibility in the academic writing practice (Gillett, 2017; Nga, 2009). Responsibility is part of the ethics of academic writing where a writer should provide relevant evidence to support his or her writing in an ethical way as a form of academic honesty by using examples (Oshima \& Hogue, 1999) and in-text citations through quoting, paraphrasing, or summarising certain ideas, information, or evidence (Gillett, 2017; Jones, 2011).

In short, this study views that the schematic structures of the argumentative writing with its academic linguistic features that have been elaborated in this paper are the ideal academic writing competencies that are expected of the students. In this study, the ideal academic writing competencies serve as the guidelines for the exploration of the students' academic writing competencies. The following section will discuss the data collection and analysis of this study.

\section{METHOD}

The aim of this study is to explore the tertiary EFL students' academic writing competencies. This study involved thirty-six first-year tertiary EFL students who took the academic writing subject in the second semester of a private university in Pontianak, West Kalimantan, Indonesia. They were from a regular class. Then, they had passed the basic writing subject focusing on the sentence and paragraph writing and had no prior knowledge of academic writing and critical thinking at the tertiary level of education.

To cope with the aim, this study employed a qualitative method that used documents as a source 
of evidence (Hamied, 2017; Stake, 2005). A writing test was conducted to the students before taking the academic writing subject. In the beginning, the students agreed to participate and had to complete and sign a consent form. The test provided an online news article to be argued or discussed, then followed by requirements to structure the writing into three elements of an argumentative writing with proper lexical choices and conventions. The elements were described in general terms without specifying to exposition or discussion genre. The requirements of the writing test are as follows:

1. The issue to develop or to defend;

2. The arguments with supporting evidence that are relevant to the issue;

3. Concluding remarks which should include a position or recommendation towards the issue;

4. Word choices or proper words or lexical choices that form good sentences that could lead to good writing;

5. Conventions that include correct spelling, punctuation, and grammar.

After the students' completion of the writing test, their writing texts were analyzed. The text analysis refers to the concept of text from the perspective of functional grammar. Following the academic writing competencies that have been elaborated earlier, the analysis focuses on the schematic structure and the linguistic features used in the texts. The results of the analysis are described in this paper following the concept of three language metafunctions, namely textual metafunction, ideational metafunction, and interpersonal metafunction of the students' text (Emilia, 2014; Halliday \& Matthiessen, 2014). Due to limited space, three texts were selected to be presented in this paper. The students were Sani who represents the low achiever, Eri who represents the medium achiever, and Ruri who represents the high achiever (pseudonyms). Still, even though the students were categorized into three different levels of writing achievement based on the results of the text analysis, the students have little differences in the control of the schematic structure and linguistic features of argumentative writing. This will be discussed further in the following section.

\section{FINDINGS AND DISCUSSION}

The findings of this research are based on the text analysis conducted to the students' texts. Three selected texts were written by Sani who represents the low achiever, Eri who represents the medium achiever, and Ruri who represents the high achiever. The texts are presented in Table 1 where the texts are divided into three elements of an argumentative writing with each clause numbered.

Table 1. The students' text

\begin{tabular}{|c|c|c|}
\hline \multicolumn{3}{|c|}{ Title and Texts } \\
\hline Untitled & $\begin{array}{l}\text { Teachers and Principals stole and } \\
\text { leaked National Exam Paper }\end{array}$ & $\begin{array}{c}\text { False claims from the } \\
\text { government about the National } \\
\text { Exam }\end{array}$ \\
\hline Sani (a low achiever) & Eri (a medium achiever) & Ruri (a high achiever) \\
\hline $\begin{array}{l}\text { Issue } \\
\text {...The main obstacle in improving the } \\
\text { quality of teachers is a budget that is } \\
\text { less in improve the quality of service } \\
\text { improvement coaching educators } \\
\text { include teacher's welfare } \\
\text { improvement and control of the } \\
\text { principal. (is the insufficient budget) } \\
\text { Argument } \\
\text { Leaking of the graduation exam now } \\
\text { called UAN and, no doubt (Leaking } \\
\text { of the National Exam key answer).... } \\
\text { Concluding remarks } \\
\text { Conclusions from reading the above is } \\
\text { supposed to be the schools and } \\
\text { teachers do not divulge national } \\
\text { examination answer keys ... }\end{array}$ & $\begin{array}{l}\text { Issue } \\
\text { It appears to me } \\
\text { that these case (this case) might be } \\
\text { happened in other district, even maybe } \\
\text { in another province... } \\
\text { Argument } \\
\text { Although, this case is not on police } \\
\text { officers (did not involve the police } \\
\text { officer) [[which (who) escorted the exam } \\
\text { questions only]] a } \\
\text { Concluding remarks } \\
\text { The teachers should not do something } \\
\text { like this only for their own selfish } \\
\text { ambition... }\end{array}$ & $\begin{array}{l}\text { Issue } \\
\text { The National Exam has been } \\
\text { stolen from inside person (by an } \\
\text { inside person)... } \\
\text { Argument } \\
\text { The National Exam must be } \\
\text { deleted by the government... } \\
\text { Concluding remarks } \\
\text { From that we know, [[some people } \\
\text { gain profit]] ... }\end{array}$ \\
\hline Notes: & nctuati & $\begin{array}{l}\text { ormation, improper pun } \\
\text { choices. }\end{array}$ \\
\hline
\end{tabular}

Table 1 shows that the three texts have many grammatical mistakes, missing or incorrect information, and improper conventions, lexical choices, and cohesive devices or conjunctions that 
interfere with the meaning and the purpose of the texts. The texts also eventually have unclear schematic structure. However, the texts show an attempt to argue the topic given on the writing test, that is, the leaking of National Exam.

The description of the analysis will begin with textual metafunction realized by Theme system and logical metafunction realized by Conjunction system, followed by experiential metafunction realized by Transitivity system and interpersonal metafunction realized by Mood system. Logical metafunction and experiential metafunction are parts of ideational metafunction (Eggins, 2004; Halliday, 1994; Halliday \& Matthiessen, 2014; Thompson, 2014).

The textual metafunction is about how a text is organized. This involved the use of conjunction that also signals logical metafunction, which links clauses, sentences, and paragraphs that build a cohesive text (Martin, 1992). The descriptions will begin with the Thematic progression of the texts. Thematic progression shows a connection of a Theme or a point of information with any earlier Theme and Rheme, which is information that follows the Theme (Emilia, 2014; Thompson, 2014).

The texts show an unclear pattern, as the texts have many limitations in grammar, conventions, lexical choices, and conjunctions. The text written by Sani does not show Thematic progression at all that can signal a unified text. For example, a clause that is indicated as a thesis statement: The main obstacle in improving the quality of teachers is a budget that is less in improve the quality of service improvement coaching educators include teacher's welfare improvement and control of the principal. However, the next paragraph, which is indicated as part of the argument element, has no topical Theme or conjunction that relates the thesis statement to the argument that follows in this clause: Leaking of the graduation exam now called UAN and, no doubt (Leaking of the National Exam key answer) because it is there the ability to think students are trained only on the ability of low level thinking skills are memorized and answered questions (was) because (of) (the view that the students trained the low level thinking skills only,). The Rheme that follows the Theme also does not reflect any relevance to the thesis statement. This shows that each paragraph of the text in the issue and argument element is not well-correlated until it reaches the last paragraph indicating the concluding remarks: Conclusions from reading the above is supposed to be the schools and teachers do not divulge national examination answer keys. The indication is signaled by a topical marked Theme that is relevant to the argument element. In relation to the CT aspects, the text shows limited information-organizing skills and intellectual standards or dispositions; more specifically, clarity, relevance, and logicalness. A similar issue was also identified in Eri's and Rick's text.

The experiential metafunction is about what happens or the content of the text, realized by Transitivity system, consisting of types of processes with their participants and circumstances (Emilia, 2014; Thompson, 2014). The three texts employed various types of processes. The three texts clearly show limitations in constructing their arguments. For example, Ruri employed a material process in the argument element to build an argument: The National Exam [Goal] must be deleted by [Pr: Material] the government (Actor). The mental process realises a reason: because [Circ: Cause: Reason] many students [Senser] fear [Pr: Affective] incomplete past the test [Phenomenon] (incomplete the test). This shows Ruri's attempt to provide a reason for the deletion of the National Exam. The reason is evidence in the form of example that is relevant to the topic (Gillett, 2017). However, the example is not clear as it has grammatical mistakes that create confusion to understand the meaning of the passage. Still, this attempt shows that the student tried to communicate his ideas by adding relevant evidence as part of responsibility in the academic writing practice even though he had no prior knowledge of academic writing and critical thinking at the tertiary level of education.

The circumstance in the earlier passage plays an important function that provides a causal relationship. Another use of circumstances is to provide clear, accurate, and specific information (Emilia \& Hamied, 2015). Without proper circumstances, a fallacy may occur. In this case, fallacies were identified in the three texts. A clause in Sani's text for example: ...many schools and teachers... indicates a fallacy where the student seems to generalize the participant that could lead to a perspective that every teacher leaks the National Exam answer key. A similar issue was also identified in Eri's and Rick's text.

In relation to the experiential metafunction, two causal relational processes are used to show the effects that will be encountered: and it [Agent] can make [Pr: Cause] them [Carrier] frustated (frustrated) [Attribute] and and the worse way they [Carrier] can [Pr: Atrributive] suicide (commit suicide) [Attribute]. Then, an attributive relational process: It (Carrier) is (Pr: Attributive) not fair (Attribute) indicates a personal comment in an objective way, as the clause uses an impersonal passive voice that has an effect on removing agency (Knapp \& Watkins, 2005). However, the supporting details provided are not clear because they have grammatical mistakes that create confusion to understand the meaning of the passages.

Interpersonal metafunction is about how language is used to interact with readers (Thompson, 2014). This is signaled mainly by the use of mood choices and modality. The mood choice of the three 
texts is mainly in declarative form that is important to provide information especially to persuade readers (Emilia \& Hamied, 2015). The persuasions in the three texts are realized by the use of modality, which is a form of hedging or cautious language (Gillett, 2017; Gillett et al., 2009).

Modality in the texts has two functions, that is, a probability (part of modalisation) and an obligation (part of modulation). The example of probability is a projected clause in Eri's text: that these case (this case) might be happened in other district, even maybe in another province. Then, obligation mainly is realized in the concluding remarks as a recommendation or a suggestion. This is exemplified in a clause in Sani's text: but they must work together constructing the students are motivated to do the exam with genuine value to this in order to get students who excel. (to develop the students' motivations to do the National Exam by their own skills.). In addition to the function, modality has three distinguished levels (low, medium, and high) that show the strength of the modality. For example, modality must show a high obligation, meanwhile, might shows a low probability (Emilia, 2014; Thompson, 2014).

Other features in the texts are impersonal passive voice and personal pronoun. Two personal pronouns were identified in Eri's and Ruri's text. A phrase in Eri's text: It appears to $\underline{m e}$ indicates that the statement that follows is a student's opinion or experience. Then, a phrase in Ruri's text: From that we know indicates an engagement with readers (Hyland, 2002) followed by reasons to strengthen the engagement. However, again, the grammatical mistakes create confusion to understand the meaning of the reasons.

Overall, the texts presented in this paper have many limitations in grammar, conventions, lexical choices, and cohesive devices or conjunctions even though a few examples of academic language were detected in the texts. In SFL, these linguistic features are fundamental to shape a meaningful academic text (Halliday, 1994).

The texts also have no clear-cut schematic structure of an argumentative writing. The same thing goes for the CT aspects where the texts show limitations in intellectual standards or dispositions and information-organizing skills as the texts have many issues related to clarity, relevance, and logicalness. Again, these limitations are caused by the limited use of grammar, convention, lexical choices, and cohesive devices which are important to construct a meaningful academic text (Halliday, 1994). Fallacies were also detected and mainly related to information generalization. These limitations interfere with the students' attempts to communicate their arguments explicitly, formally, logically, and responsibly.

Certainly, these limitations occurred because of two reasons. The first reason is that the test was conducted in a limited time. Meanwhile, writing is a recursive process (Emilia, 2005) that takes time for the students to accustom to such a long process. As a result, the students were unable to fulfill the ideal academic writing competencies that were demanded in the test.

The second reason is, that the students had no prior knowledge of academic writing and critical thinking even though the students had already learned sentence and paragraph writing in the first semester. They were also already introduced to the exposition and discussion genres in the senior high school as demanded in the Indonesian national curriculum (Kemdikbud RI, 2014). Unfortunately, this study shows that they had insufficient knowledge and skills to cope with the academic writing at the tertiary level of education. This means that the lecturer has an abundance of tasks to develop the students' academic writing that can reflect their CT capacity.

To cope with this issue, this study would like to propose the implementation of the genre-based approach (GBA) that has been used around the world, including in Indonesia (Derewianka, 2003; Emilia, 2005) in which should include the teaching of character values (Aunurrahman, Hamied, \& Emilia, 2016; Hardini, 2013), enhancement of academic writing, and development of critical thinking (Emilia, 2005; Emilia \& Hamied, 2015). The GBA that is proposed is based on SFL (Halliday, 1978, 2007; Hasan, 2014) and developed by Sydney school (Christie \& Martin, 2008; Derewianka, 2012; Feez, 2002).

In brief, the GBA emphasizes explicit teaching that occurs when the lecturer explicitly elaborates what has been done to the students in constructing an academic text. As a result, the students can focus on the things that have not been done. The explicit teaching can be reduced when the students are considered ready to work in an individual setting (Feez, 2002). To facilitate an effective learning especially to cope with large classes that are common in Indonesia, the lecturer also can use group work by grouping the low achievers with the medium and high achievers. This will allow the medium and high achievers to assist the low achievers in constructing an academic text before they work individually (Aunurrahman et al., 2016).

\section{CONCLUSION}

The study aims to explore the academic writing competencies of the tertiary EFL students of a private university in Pontianak, West Kalimantan, Indonesia. The findings show that the students have little control over the schematic structure and linguistic features of argumentative writing. This also reflects limitations of information-organizing skills that reflect the students' critical thinking capacity. Other limitations are limited intellectual 
standards or dispositions and fallacies in reasoning. Still, several examples of academic language were identified in the students' texts.

An approach that addresses these issues is the systemic functional linguistics genre-based approach with its explicit teaching. Group work should also be incorporated into the approach, as tertiary level educational institutions in Indonesia commonly have large classes. Moreover, future research can explore graduate students' academic writing competencies in the Indonesian university context.

\section{REFERENCES}

Aunurrahman, Hamied, F. A., \& Emilia, E. (2016). Facilitating character building through an academic writing practice. Arab World English Journal, 7(3), 146-160.

Bruce, I. (2008). Academic writing and genre: A systematic analysis. New York, NY: Continuum.

Bruce, I. (2013). A role for genre-based pedagogy in academic writing instruction: An EAP perspective. TEXT Journal, (21), 1-15.

Celce-Murcia, M., Dörnyei, Z., \& Thurrell, S. (1995). Communicative competence: A pedagogically motivated model with content specifications. Issues in Applied Linguistics, 6(2), 5-35.

Christie, F., \& Martin, J. R. (Eds.). (2008). Language, knowledge and pedagogy: Functional linguistic and sociological perspectives. New York, NY: Continuum.

Coffin, C. (2004). Arguing about how the world is or how the world should be: The role of argument in IELTS tests. Journal of English for Academic Purposes, 3(3), 229-246. https://doi.org/10.1016/j.jeap.2003.11.002

Coffin, C., \& Donohue, J. P. (2012). Academic literacies and systemic functional linguistics: How do they relate? Journal of English for Academic Purposes, 11(1), 64-75. https://doi.org/10.1016/j.jeap.2011.11.004

DasBender, G. (2011). Writing spaces: Readings on writing (Vol. 2). Anderson, SC: Parlor Press. Retrieved from http://wac.colostate.edu/books/writingspaces2/

Derewianka, B. (1990). Exploring how texts work. Rozelle, NSW: Primary English Teaching Association.

Derewianka, B. (2003). Trends and issues in genrebased approaches. RELC Journal, 34(2), 133154. https://doi.org/10.1177/003368820303400202

Derewianka, B. (2012). Knowledge about language in the Australian curriculum: English. Australian Journal of Language and Literacy, 35(2), 127-146.
Derewianka, B. (2015). The contribution of genre theory to literacy education in Australia. In J. Turbill, G. Barton, \& C. H. Brock (Eds.), Teaching writing in today's classrooms: Looking back to looking forward (pp. 69-86). Norwood, Australia: Australian Literary Educators' Association. Retrieved from http://ro.uow.edu.au/sspapers/1621

Dörnyei, Z., \& Thurrell, S. (1991). Strategic competence and how to teach it. ELT Journal, 45(1), 16-23. https://doi.org/10.1093/elt/45.1.16

Eggins, S. (2004). An introduction to systemic functional linguistics (2nd ed.). New York: Continuum.

Elder, L., \& Paul, R. (2010, October). Universal intellectual standards. Retrieved December 6, 2014, from http://www.criticalthinking.org/pages/universal -intellectual-standards/527

Elder, L., \& Paul, R. (2013). Critical thinking: Intellectual standards essential to reasoning well within every domain of human thought. Journal of Developmental Education, 36(3), 34-35.

Emilia, E. (2005). A critical genre-based approach to teaching academic writing in a tertiary EFL context in Indonesia (Unpublished Dissertation). The University of Melbourne, Melbourne. Retrieved from https://minervaaccess.unimelb.edu.au/handle/11343/39548

Emilia, E. (2009). Menulis tesis dan disertasi. Bandung, Indonesia: Alfabeta. Retrieved from http://alifviaarviningrum.studentsblog.undip.ac.id/files/2010/10/Tesis-danDisertasi-9-Rev-Sept08.pdf

Emilia, E. (2012). Pendekatan genre-based dalam pengajaran bahasa Inggris: Petunjuk untuk guru (2nd ed.). Bandung, Indonesia: Rizqi Press.

Emilia, E. (2014). Introducing functional grammar. Bandung, Indonesia: Pustaka Jaya.

Emilia, E., \& Hamied, F. A. (2015). Systemic functional linguistic genre pedagogy (SFL GP) in a tertiary EFL writing context in Indonesia. TEFLIN Journal, 26(2), 155-182. https://doi.org/10.15639/teflinjournal.v26i2/15 5-182

Ennis, R. H. (1993). Critical thinking assessment. Theory into Practice, 32(3), 179-186.

Ennis, R. H. (1996). Critical thinking dispositions: Their nature and assessability. Informal Logic, $18(2 \& 3), 165-182$.

Ennis, R. H. (2013). Critical thinking across the curriculum (CTAC). In D. Mohammed \& Marcin Lewiński (Eds.), Proceedings of the Ontario Society for the Study of Argumentation Conference (Vol. 10, p. 44). Canada: University of Windsor. Retrieved from 
http://scholar.uwindsor.ca/ossaarchive/OSSA1

0/papersandcommentaries/44/

Ennis, R. H. (2016). Definition: A threedimensional analysis with bearing on key concepts. In L. Benacquista \& P. Bondy (Eds.), Proceedings of the Ontario Society for the Study of Argumentation Conference (Vol. 11, p. 150). Canada: University of Windsor. Retrieved from http://scholar.uwindsor.ca/ossaarchive/OSSA1 1/papersandcommentaries/105/

Feez, S. (2002). Heritage and innovation in second language education. In A. M. Johns (Ed.), Genre in the classroom: Multiple perspectives (pp. 47-68). Mahwah, NJ: Lawrence Erlbaum.

Gillett, A. (2017, March 17). Features of academic writing. Retrieved April 7, 2017, from http://www.uefap.com/writing/feature/featfram .htm

Gillett, A., Hammond, A., \& Martala-Lockett, M. (2009). Successful academic writing. London, UK: Pearson Education.

Halliday, M. A. K. (1978). Language as social semiotic: the social interpretation of language and meaning. London: Edward Arnold.

Halliday, M. A. K. (1994). An introduction to functional grammar (2nd ed.). London, UK: Edward Arnold.

Halliday, M. A. K. (2007). Language and education. (J. J. Webster, Ed.). New York, NY: Continuum.

Halliday, M. A. K., \& Matthiessen, C. M. I. M. (2014). Halliday's introduction to functional grammar (4th ed.). Oxfordshire, UK: Routledge.

Hardini, S. R. (2013, October 10). Developing character values in the teaching of narrative texts using genre based approach: A case study at a senior high school in Bandung (unpublished postgraduate thesis). Universitas Pendidikan Indonesia, Bandung, Indonesia. Retrieved from http://repository.upi.edu/2181/

Hasan, R. (2014). Towards a paradigmatic description of context: Systems, metafunctions, and semantics. Functional Linguistics, 1(1), 154.

Hyland, K. (2002). Academic argument: Induction or interaction. Revista Canaria de Estudios Ingleses, 44(1), 29-45.

Irvin, L. L. (2010). What is "Academic" writing? In Writing spaces: Readings on writing (Vol. 1), pp. 3-17. West Lafayette, IN: Parlor Press.

Jones, L. R. (2011). Academic integrity \& academic dishonesty: A handbook about cheating \& plagiarism (Revised \& Expanded Edition). Melbourne, Florida: Florida Institute of Technology. Retrieved from https://www.fit.edu/current/documents/plagiari sm.pdf
Kemdikbud RI. (2014). Peraturan menteri pendidikan dan kebudayaan Republik Indonesia nomor 49 tahun 2014 tentang kompetensi inti dan kompetensi dasar pelajaran pada kurikulum 2013 pada pendidikan dasar dan pendidikan menengah.

Knapp, P., \& Watkins, M. (2005). Genre, text, grammar: Technologies for teaching and assessing writing. Sydney: UNSW Press.

Kurfiss, J. G. (1997). Critical thinking: Theory, research, practice, and possibilities.

Washington, D.C.: Graduate School of Education and Human Development, George Washington University.

Lipman, M. (2003). Thinking in education (2nd ed.). New York, US: Cambridge University Press. Retrieved from http://dx.doi.org/10.1017/CBO9780511840272

Maguire, M., Reynolds, A. E., \& Delahunt, B. (2013). Self-efficacy in academic reading and writing, authorial identity and learning strategies in first-year students. AISHE-J: The All Ireland Journal of Teaching and Learning in Higher Education, 5(1). Retrieved from http://ojs.aishe.org/index.php/aishej/article/viewArticle/111

Malik, R. S., \& Hamied, F. A. (2014). Research methods: A guide for first time researchers. Bandung, Indonesia: UPI Press.

Martin, J. R. (1992). English text: System and structure. Philadelphia: John Benjamins Pub. Co.

Martin, J. R., \& Rose, D. (2008). Genre relations: Mapping culture. London, UK: Equinox Publishing.

Nga, N. T. H. (2009). Academic English at tertiary level: What, why and how. VNU Journal of Science, Foreign Languages, 25, 112-117.

Nugraha, A. K. E. (2015, August 26). Mahasiswa Indonesia masih lemah menulis karya ilmiah. Rakyatku.Com. Retrieved from http://rakyatku.com/2015/08/26/edukasi/mahas iswa-indonesia-masih-lemah-menulis-karyailmiah.html

Oshima, A., \& Hogue, A. (1999). Writing academic English (3rd ed.). New York: Addison Wesley Longman.

Schleppegrell, M. J. (2012). Academic language in teaching and learning: Introduction to the special Issue. The Elementary School Journal, 112(3), 409-418. https://doi.org/10.1086/663297

Siegel, H. (2010). Critical thinking. International Encyclopedia of Education, 6, 141-145. https://doi.org/10.1016/B978-0-08-0448947.00582-0

Stake, R. E. (2005). Qualitative case studies. In N. K. Denzin \& Y. S. Lincoln (Eds.), The Sage handbook of qualitative research (3rd ed, pp. 
Aunurrahman, Hamied, and Emilia, Exploring the tertiary EFL students'...

443-466). California, US: SAGE Publications, Inc.

Thompson, G. (2014). Introducing functional grammar (3rd ed.). New York: Routledge.

White, M. J. (1988, November). An analysis of the academic writing of Indonesian graduate students at Simon Fraser university: The process and the product (Unpublished Thesis). Simon Fraser University, Canada. Retrieved from

http://summit.sfu.ca/system/files/iritems1/5341 /b15012025.pdf 